Folia Cardiologica 2018

\title{
Badanie EKG metodą Holtera u chorego z urządzeniem wszczepialnym - przykłady algorytmów ograniczających stymulację prawej komory
}

\author{
Holter ECG in a patient with an implantable device: \\ examples of algorithms to avoid right ventricular pacing
}

\author{
Ewa Szczerba ${ }^{1,2}$, Andrzej Cacko ${ }^{1,3}$, Renata Główczyńska ${ }^{1}$ \\ ${ }^{1}$ I Katedra i Klinika Kardiologii Warszawskiego Uniwersytetu Medycznego \\ ${ }^{2}$ Zakład Kardiologii Instytutu Matki i Dziecka w Warszawie \\ ${ }^{3}$ Zakład Informatyki Medycznej i Telemedycyny Warszawskiego Uniwersytetu Medycznego
}

\section{Streszczenie}

Wysoki odsetek stymulacji prawej komory u chorych z urządzeniami wszczepialnymi wiąże się z większą częstością niekorzystnych zdarzeń klinicznych, takich jak zaostrzenia niewydolności serca czy migotanie przedsionków. Szczególną grupą chorych, u których należy dążyć do unikania stymulacji prawej komory, są pacjenci z niewydolnością serca z niską frakcją wyrzutową, u których wszczepiono jedno- lub dwujamowy układ kardiowertera-defibrylatora. W przypadku układów dwujamowych redukcję stymulacji prawokomorowej można uzyskać, posługując się odpowiednim programowaniem odstępu przedsionkowo-komorowego (AV) lub programami/trybami stymulacji, na przykład AAI/DDD lub DDD/ADI, które pozwalają na aktywne promowanie własnego przewodzenia AV. Istnieją również algorytmy łączące elementy powyższych metod, mające na celu zminimalizowanie częstości stymulacji prawokomorowej. Liczne sposoby programowania przypominają nieprawidłowe funkcjonowanie urządzenia wszczepialnego, symulując niedoczułość lub nadczułość układu, mogą stanowić duże wyzwanie dla lekarza opisującego badanie elektrokardiograficzne (EKG) metodą Holtera. Zaprezentowano przykłady zapisów algorytmów zmniejszających odsetek stymulacji prawej komory zarejestrowanych w badaniu EKG metodą Holtera.

Słowa kluczowe: Holter EKG, unikanie stymulacji prawej komory, elektrokardiogram

Folia Cardiologica 2018; 13, 1: 86-95

\section{Wstęp}

Obecnie wiadomo, że długotrwała stymulacja prawej komory wywołuje niekorzystne skutki na poziomie molekularnym i hemodynamicznym, co ma następstwa kliniczne. Zmiany na poziomie kardiomiocytów, włóknienie śródmiąższowe, zastępowanie miokardium przez tkankę tłuszczową doprowadzają do asymetrycznego przerostu lewej komory. Konsekwencją jest zmieniona geometria skurczu lewej komory, szczególnie wyrażona w upośledzonej funkcji podłużnej i ruchu skrętnego, co skutkuje zmianą w funkcji hemodynamicznej serca, prowadząc do zmniejszenia objętości wyrzutowej oraz do zmian w funkcjonowaniu aparatu podzastawkowego zastawki mitralnej. Dodatkowo dochodzi do wydłużenia czasu przewodzenia śródkomorowego i asynchronii skurczu [1, 2]. Miejsce stymulacji prawokomorowej ma również wpływ na ekspresję genów dla białek odpowiedzialnych za regulację metabolizmu kardiomiocytu i jego kurczliwości [3]. 
W badaniach wykazano, że wyższy odsetek stymulacji prawokomorowej zwiększał ryzyko hospitalizacji z powodu niewydolności serca i przetrwałego lub utrwalonego migotania przedsionków, choć w niektórych pracach nie obserwowano takich zależności względem zgonów, hospitalizacji z przyczyn sercowo-naczyniowych, epizodów migotania przedsionków czy konieczności wykonania kardiowersji $[4,5]$. W badaniu MOST (MOde Stelection Trail) u chorych z niewydolnością węzła zatokowego wykazano, że odsetek stymulacji prawej komory ponad $40 \%$ wiązał się z 3-krotnym wzrostem ryzyka hospitalizacji z powodu niewydolności serca, a z każdym zwiększeniem odsetka stymulacji prawej komory o $25 \%$ ryzyko migotania przedsionków zwiększało się o ponad 30\%. W tym badaniu nie obserwowano wpływu stymulacji prawokomorowej na śmiertelność całkowitą ani liczbę udarów mózgu [6]. Z kolei w badaniu DAVID (Dual Chamber and VVI Implantable Defibrillator), do którego włączano chorych wymagających wszczepiania układu kardiowertera-defibrylatora w prewencji pierwotnej lub wtórnej nagłego zgonu sercowego, zaobserwowano, że chorzy, u których odsetek stymulacji prawokomorowej przekraczał 40\%, mieli zwiększone ryzyko zgonu lub hospitalizacji z powodu niewydolności serca [7].

Najprostszym rozwiązaniem wydawałoby się wykorzystanie układów stymulujących serca wyłącznie z elektrodą przedsionkową u wszystkich chorych, którzy nie mają udokumentowanego bloku przewodzenia przedsionkowo-komorowego (AV, atrioventricular). Jednocześnie aktualne wytyczne Europejskiego Towarzystwa Kardiologicznego (ESC, European Society of Cardiology) dotyczące stymulacji serca promują wykorzystanie układów stymulujących z implantacją elektrody przedsionkowej i komorowej - są to urządzenia pierwszego wyboru u większości chorych [8]. W związku z tym szczególne znaczenie mają algorytmy ograniczające liczbę stymulacji komorowej.

Dane z badań dotyczących skuteczności klinicznej algorytmów ograniczających stymulację prawej komory jeszcze bardzie zaciemniają obraz kliniczny. Pomimo ich skuteczności w zakresie zmniejszania odsetka stymulacji komorowej, dane dotyczące korzyści względem takich punktów końcowych, jak hospitalizacje z powodu niewydolności serca, migotanie przedsionków czy zgony, są nieliczne i niejednoznaczne, choć może to wynikać z niedoskonałości samych algorytmów, a nie z błędnych założeń patofizjologicznych [9]. W badaniu SAVE PACe (Search AV Extension and Managed Ventricular Pacing for Promoting Atrioventricular Conduction) zastosowanie algorytmu ograniczającego stymulację prawej komory zmniejszało ryzyko przetrwałego lub utrwalonego migotania przedsionków, jednak nie wpływało na śmiertelność ani na liczbę hospitalizacji z powodu niewydolności serca [10].

Istnieją różne grupy metod, które mogą się przyczynić do ograniczenia negatywnych konsekwencji stymulacji prawokomorowej: lokalizacja końcówki elektrody komoro- wej w górnej części przegrody międzykomorowej, programowanie urządzenia z zamysłem ograniczenia stymulacji komorowej, wszczepienie układu resynchronizującego w przypadku przewidywanego wysokiego odsetka stymulacji komorowej [9]. Wśród metod programowania urządzenia należy wymienić tryby stymulacji DDD ze zmiennym opóźnieniem AV (tzw. pozytywna histereza) lub stałym długim odstępem AV oraz tryby stymulacji przedsionkowej z wyczuwaniem w kanale komorowym i zabezpieczająca stymulacją komorową - ADI(R)-DDD(R) [11]. W wytycznych dotyczących stymulacji serca i terapii resynchronizującej ESC opublikowanych w 2013 roku znajdują się wskazówki, u których chorych należy zapobiegać stymulacji prawej komory poprzez optymalizację odstępu AV, lub programowanie histerezy AV. Powinien to być pierwszy sposób programowania stymulatorów u osób z chorobą węzła zatokowego oraz z przemijającymi zaburzeniami przewodnictwa AV [8]. Podobne zalecenia dotyczą sposobu programowania układu kardiowertera-defibrylatora (ICD, implantable cardioverter defibrillators) w zależności od współistniejących chorób układu bodźcoprzewodzącego serca.

\section{Opis przypadków}

Poniżej zaprezentowano zapisy badań elektrokardiograficznych (EKG) metodą Holtera u 2 pacjentów, gdzie zastosowano algorytmy ograniczające stymulację prawej komory, które mogą zaskoczyć lekarza opisującego badanie EKG.

Pierwszy zapis badania EKG metodą Holtera należy do 62-letniego mężczyzny z układem ICD (Medtronic Maximo II DR) AV wszczepionego w ramach prewencji pierwotnej nagłego zgonu sercowego, który wykonywano w celu oceny arytmii komorowej. Szczegóły dotyczące sposobu zaprogramowania parametrów stymulacji urządzenia przedstawiono na rycinie 1.

W zapisie EKG metodą Holter obserwowano epizody bloku AV II stopnia prowadzące do pojawienia się pauz maksymalnie do 2,3 s (ryc. 2, 3). Można w takim wypadku podejrzewać zaburzenia sterowania o typie nadczułości elektrody komorowej. Jednak po każdym takim epizodzie dochodziło do skutecznej stymulacji sekwencyjnej z krótkim odstępem AV, wynoszącym 80 ms (ryc. 2, 3). Czy takie zachowanie układu ICD można uznać za prawidłowe? W urządzeniach firmy Medtronic dostępnym algorytmem unikania stymulacji prawej komory jest algorytm MVP (managed ventricular pacing). Istotą tego algorytmu jest zmiana trybu stymulacji w zależności od skuteczności przewodzenia AV.

Ogólną ideę algorytmów zmieniających tryb stymulacji przedstawiono na rycinie 4. Urządzenie zaprogramowane z aktywnym algorytmem MVP, w przypadku braku przewodzenia AV pracuje w trybie $\mathrm{DDD}(\mathrm{R})$ - stymulacji komorowej w odpowiedzi na pobudzenia własne przedsionkowe lub sekwencyjnej stymulacji AV z zaprogramowanym 


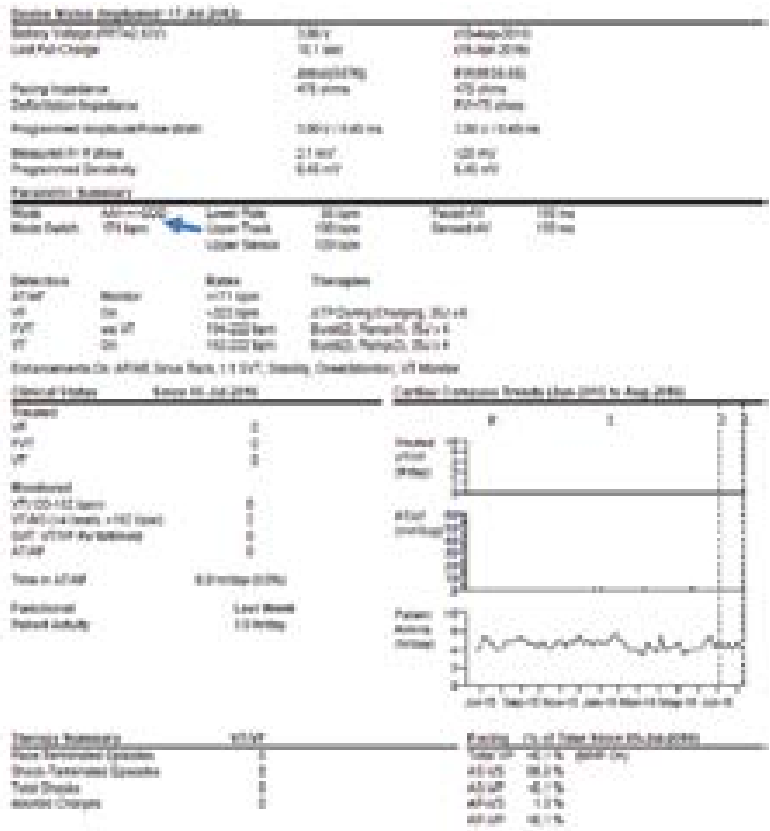

Rycina 1. Parametry stymulacji, detekcji i terapii tachyarytmii u pierwszego; strzałką zaznaczono informację o aktywnym algorytmie MVP (managed ventricular pacing) i odsetku stymulacji komorowej

czasem AV. W regularnych odstępach czasu urządzenie przechodzi w tryb stymulacji $A D I(R)$ na jeden cykl pracy serca w celu określenia skuteczności przewodzenia AV. Jeżeli w trakcie takiego interwału międzyprzedsionkowego urządzenie nie wykryje pobudzenia komorowego wraca do pracy w trybie $\operatorname{DDD}(\mathrm{R})$. Wiąże się to z możliwością wystąpienia pauzy (braku pojedynczego pobudzenia komorowego). Czas między testami ulega podwojeniu po każdej nieudanej próbie (wynosi odpowiednio 2 min, następnie
$4 \mathrm{~min}, 8 \mathrm{~min}, 16 \mathrm{~min}$ itd.) do maksymalnie 16 h. Oznacza to, że w przypadku wystąpienia utrwalonego bloku całkowitego AV co najmniej raz w ciągu doby zostanie odnotowana przerwa wynikająca z braku stymulacji komorowej między dwoma wykrytymi lub wystymulowanymi pobudzeniami przedsionkowymi.

U pacjentów z zachowanym przewodzeniem AV urządzenie pracuje w trybie ADI(R) - stymulacja występuje jedynie w kanale przedsionkowym, zabezpieczając minimalną częstość pracy przedsionków, a równocześnie w kanale komorowym obserwuje się pobudzenia komorowe. Dla algorytmu MVP bardzo charakterystyczny jest zapis rejestrowany w przypadku wystąpienia nieskutecznego przewodzenia AV w trakcie stymulowanego rytmu przedsionkowego: po wykryciu braku pobudzenia komorowego w pojedynczym interwale międzyprzedsionkowym (między kolejnymi stymulacjami przedsionkowymi) po kolejnej stymulacji przedsionkowej zostanie dostarczona stymulacja komorowa zabezpieczająca (VBP, ventricular backup pacing) z krótkim czasem AV wynoszącym 80 ms. W przypadku niezarejestrowania pobudzenia komorowego w dwóch z czterech kolejnych interwałów międzyprzedsionkowych urządzenie przechodzi w tryb DDD(R) z zaprogramowanym wcześniej czasem AV.

Szczególną właściwością algorytmu MVP, o której trzeba szczególnie pamiętać, programując urządzenia wszczepialne i oceniając ich funkcję w badaniu EKG metodą Holtera, jest dopuszczanie bardzo długich czasów AV w wyniku działania algorytmu. Podczas stymulacji w trybie $A D I(R)$ jedynym warunkiem skuteczności przewodzenia AV jest rejestracja kolejnych pobudzeń komorowych między interwałami międzyprzedsionkowymi. Oznacza to, że rejestracja pobudzenia komorowego w którymkolwiek momencie między pobudzeniami przedsionkowymi spełni warunek skuteczności stymulacji, nawet jeżeli pobudzenie

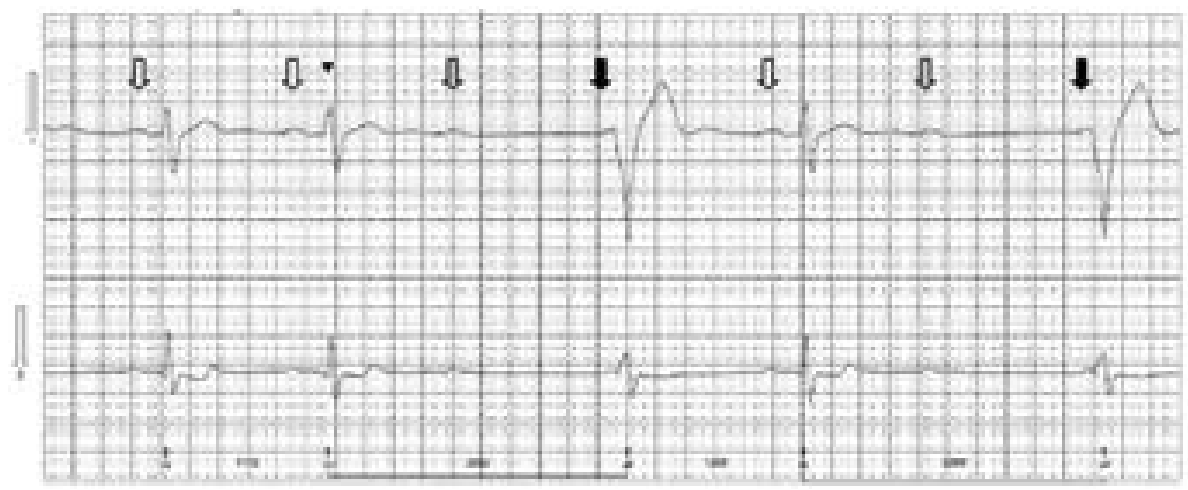

Rycina 2. Przykład działania algorytmu MVP (managed ventricular pacing). Dwa pierwsze wystymulowane pobudzenia przedsionkowe (oznaczone pustą strzałką) są przewodzone do komór z czasem przedsionkowo-komorowym (AV, atrioventricular) około $330 \mathrm{~ms}$. Trzecie i szóste wystymulowane pobudzenie przedsionkowe (oznaczone szarą strzałką) nie zostało przewiedzione do komór. W związku z tym po czwartym i siódmym wystymulowanym pobudzeniu przedsionkowym (oznaczone czarną strzałką) zarejestrowano stymulację komorową z krótkim czasem AV (80 ms) 


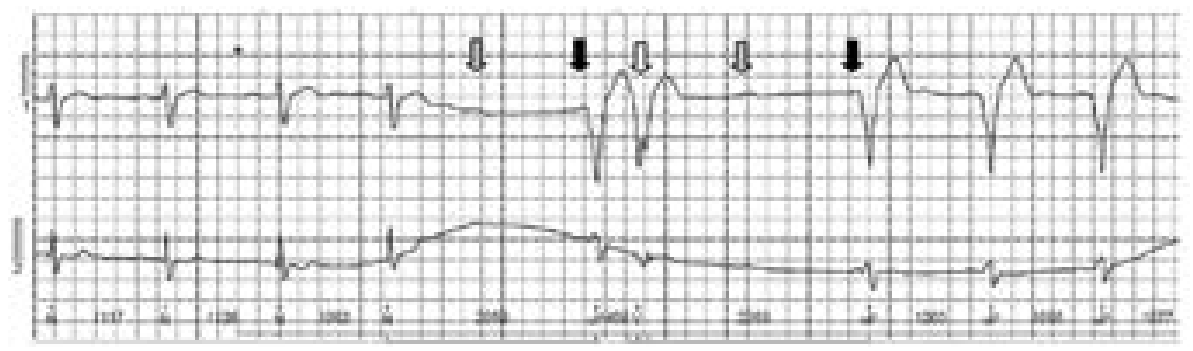

Rycina 3. Przykład działania algorytmu MVP (managed ventricular pacing). Czwarte i szóste wystymulowane pobudzenia przedsionkowe (oznaczone szarymi strzałkami) nie zostały przewiedzione do komór. W związku z tym po piątym i siódmym wystymulowanym pobudzeniu przedsionkowym (oznaczone czarnymi strzałkami) występuje stymulacja komorowa z krótkim czasem przedsionkowo-komorowym (AV, atrioventricular) (80 ms). Ponieważ zostaje spełniony warunek dwóch z czterech kolejnych pobudzeń przedsionkowych nieprzewiedzionych do komór, urządzenie zmienia tryb stymulacji z ADI na DDD. Po dwóch ostatnich wystymulowanych pobudzeniach przedsionkowych pojawia się stymulacja komorowa z zaprogramowanym czasem AV. W zapisie zarejestrowano dodatkowe pobudzenie komorowe (oznaczone białą strzałką), które zapewne zostało zarejestrowane przez urządzenie, ale nie wpływa na warunek zmiany trybu stymulacji

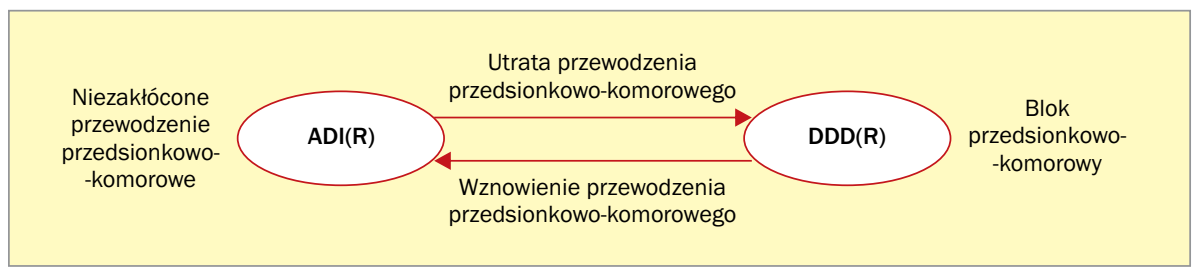

Rycina 4. Idea zmiany trybu stymulacji w zależności od skuteczności przewodzenia przedsionkowo-komorowego

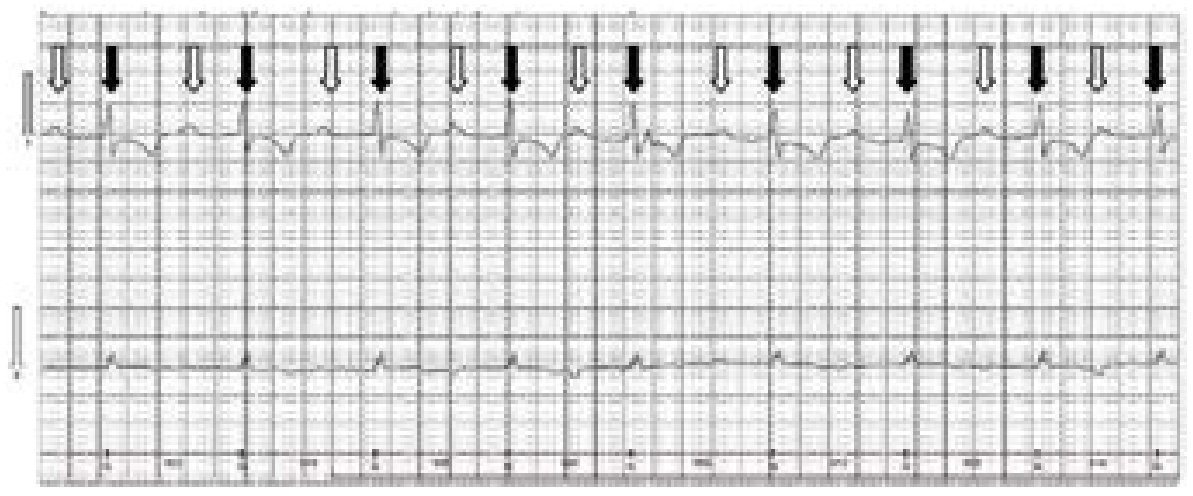

Rycina 5. Dopuszczanie przez urządzenie bardzo długiego czasu przewodzenia przedsionkowo-komorowego. Białymi strzałkami oznaczono własne pobudzenia przedsionkowe, a czarnymi - własne pobudzenia komorowe

komorowe wystąpi tuż przed pobudzeniem przedsionkowym z czasem AV wynoszącym 400, 500 i więcej ms.

$\mathrm{U}$ chorego wykonano kontrolę urządzenia przed badaniem EKG metodą Holtera i po badaniu. W kontroli wykonanej przed tym badaniem, kiedy był włączony algorytm MVP, odsetek stymulacji komorowej wyniósł mniej niż 0,1\%, a w kontroli wykonanej kilka miesięcy później, gdy algorytm ten był wyłączony, odsetek ten wzrósł do 8,4\%.

Drugi zapis badania EKG metodą Holtera należy do 58-letniego mężczyzny, któremu wszczepiono układ CDI
AV firmy Boston Scientific ENERGEN ICD F142 w prewencji pierwotnej nagłego zgonu sercowego. W zapisie EKG metodą Holtera uwagę zwracało dopuszczanie przez urządzenie bardzo długiego czasu przewodzenia AV, nawet do $400 \mathrm{~ms}$. Przy tym nie obserwowano "wypadania" pojedynczych pobudzeń komorowych. W trakcie badania rejestrowano zmienny czas trwania odstępu AV, stopniowe wydłużanie odstępu AV w kolejnych cyklach serca (ryc. 5, 6). Czy prawidłowo działający układ ICD może dopuszczać tak długie czasy przewodzenia AV? 

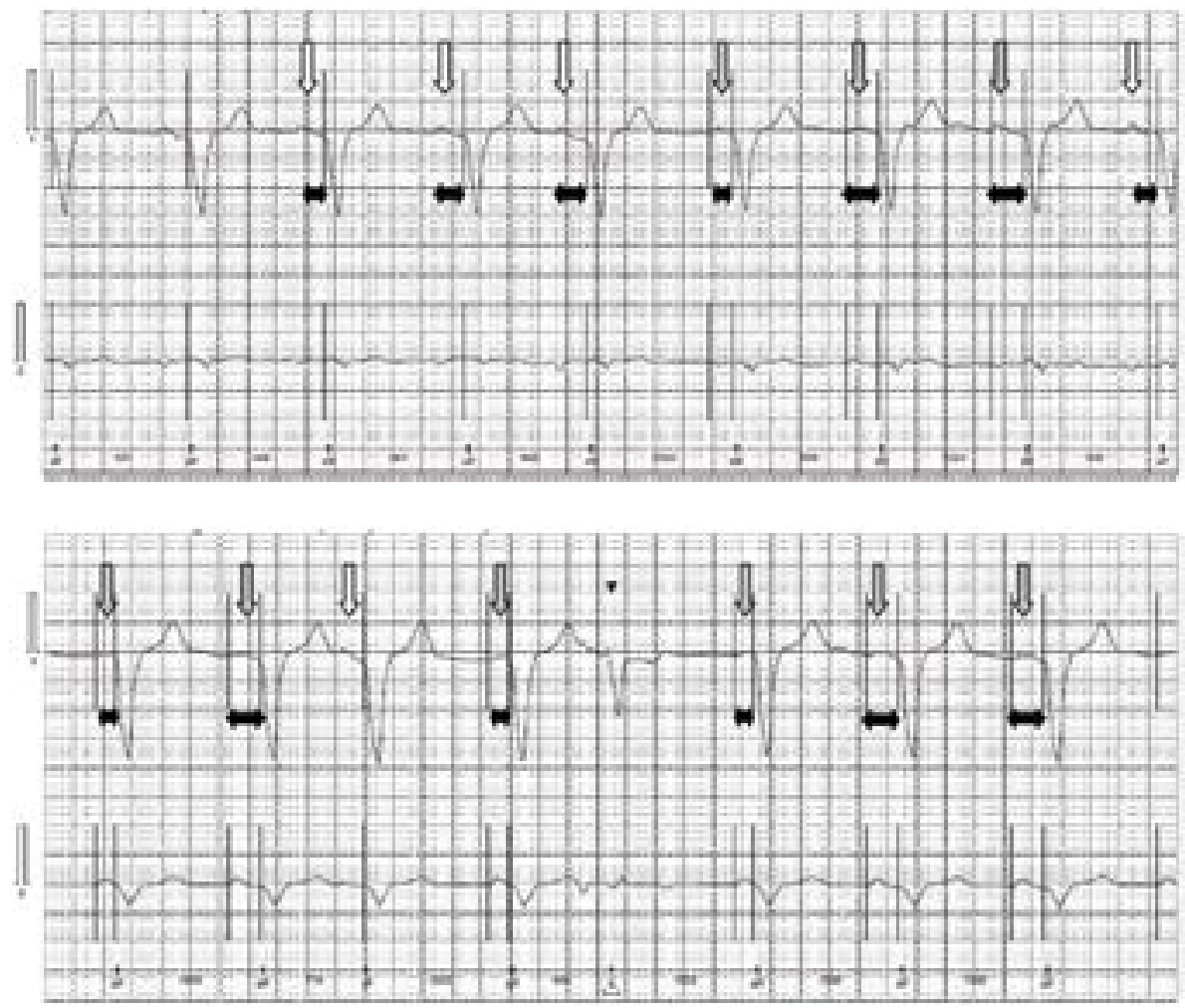

Rycina 6A, B. Wydłużanie odstępu przedsionkowo-komorowego (AV, atrioventricular) służące promowaniu własnego rytmu. Białymi strzałkami oznaczono własne pobudzenia przedsionkowe, szarymi - pobudzenia wystymulowane. Czarnymi strzałkami oznaczono odstępy AV. Zwraca uwagę stopniowe wydłużanie czasu AV w przypadku kolejnych cykli serca. Uwaga! Urządzenie rozróżnia pobudzenia przedsionkowe własne pacjenta i wystymulowane, wprowadzając pozorną nieregularność zapisu. Zapisy A i B pochodzą z tego samego badania elektrokardiograficznego metodą Holtera z różnych okresów doby

Programowanie dynamicznego odstępu AV jest jedną z metod unikania stymulacji komorowej dostępną w wielu modelach stymulatorów i ICD niezależnie od firmy produkującej urządzenie. Innym zagadnieniem pozostaje zysk kliniczny dopuszczania tak długiego czasu przewodzenia $\mathrm{AV}$, co omówiono $w$ dyskusji. W urządzeniach firmy Boston Scientific algorytm dopuszczający wydłużony czas AV (dopuszczający pozytywną histerezę czasu AV) nazywa się AV Search Hysteresist. W urządzeniach innych producentów można odnaleźć algorytmy o podobnym działaniu - stopniowe lub nagłe wydłużenie czasu AV w celu oceny efektywności przewodzenia AV, dopuszczenie wydłużonego (do określonej granicy, zwykle między 300 a 400 ms) czasu AV w kolejnych ewolucjach, skrócenie czasu AV do wyjściowo zaprogramowanej wartości w przypadku niestwierdzenia przewiedzionego pobudzenia komorowego w ustalonym oknie czasowym. U tego chorego można było obserwować również sekwencyjną stymulację dwujamową oraz stymulację w trybie VAT (ryc. 7).

\section{Dyskusja}

W obecnie wszczepianych układach stymulujących serca i układach ICD są dostępne różne funkcje, których celem jest zmniejszenie liczby stymulacji komorowych. Najpopularniejsze są algorytmy wydłużające czas AV. Znajomość podstawowych zasad działania tych algorytmów oraz ich charakterystycznych elementów pozwala rozwiązać wiele zagadek EKG.

Jednocześnie, mimo dowodów na niekorzystne działanie dużego odsetka stymulacji prawokomorowej, należy być ostrożnym w wykorzystaniu algorytmów prewencji stymulacji prawokomorowej w programowaniu układów do elektroterapii serca. Po pierwsze, u chorych z wydłużonym własnym przewodzeniem AV promowanie własnego przewodzenia może mieć niekorzystne konsekwencje hemodynamiczne i skutkować wystąpieniem objawów zespołu stymulatorowego (podczas nakładania się załamków T i P kolejnych cykli serca). Zbyt długie przewodnictwo AV doprowadza do zakłócenia optymalnego napełniania lewej komory i zmniejsza rzut serca [12]. Może również powodować zwiększenie niedomykalności mitralnej, a w konsekwencji sprzyjać zaostrzeniem niewydolności serca [8]. W wytycznych istnieją nawet wskazania do wszczepienia układu stymulującego serce $u$ chorych z blokiem AV I stopnia z odstępem PQ powyżej 300 ms przy współwystępowaniu objawów podobnych do zespołu stymulatorowego (klasa zaleceń Ila, poziom dowodów C) [8]. 


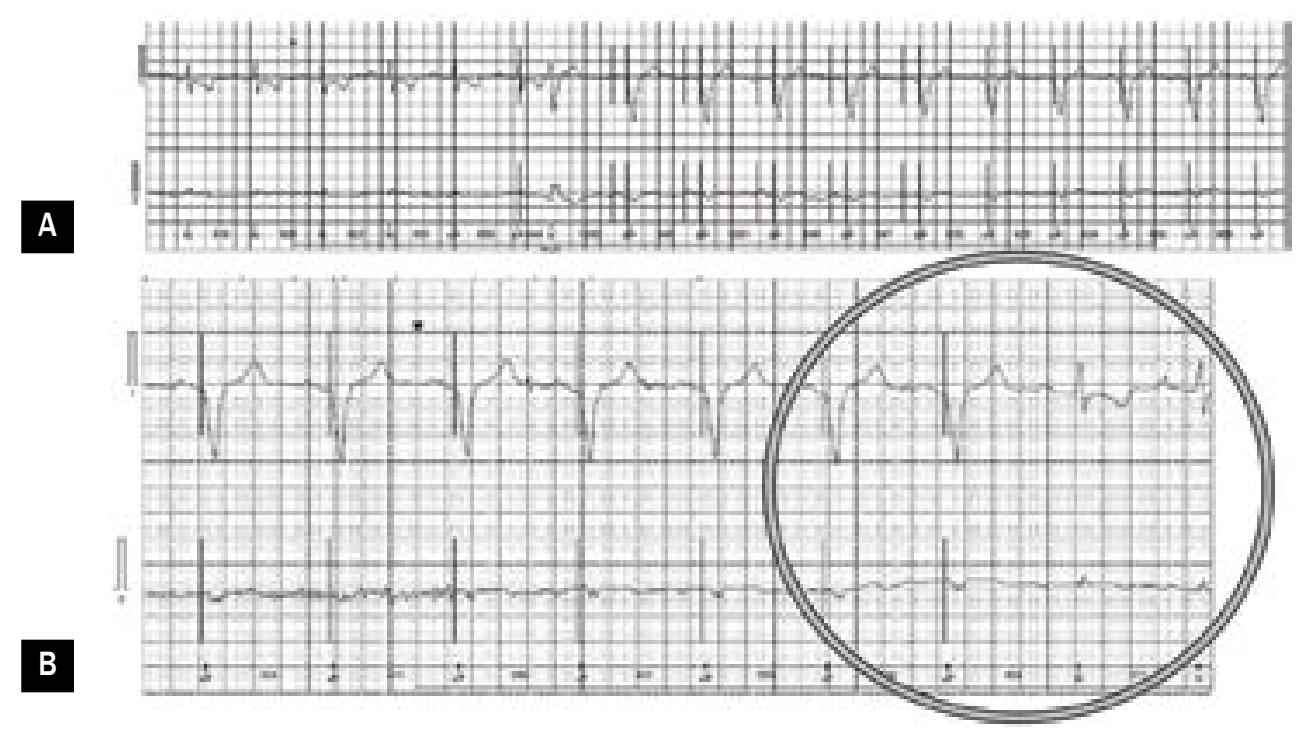

Rycina 7A, B. Fragment zapisu badania elektrokardiograficznego (EKG) metodą Holtera. W zapisie A pobudzenia przedsionkowe własne przewodzone do komór z czasem AV około 350 ms, następnie pobudzenie komorowe przewiedzione wstecznie, które zakłóciło rytm serca; stymulacja sekwencyjna przedsionkowo-komorowa (AV, atrioventricular), stymulacja w trybie VAT. W zapisie B wydłużenie czasu AV, po którym zostaje rozpoznane przewiedzione pobudzenie komorowe, po tymczasowym wydłużeniu czasu AV zainicjowanym przez algorytm dodatniej histerezy opóźnienia AV. W kolejnym cyklu serca zostanie dopuszczony wydłużony czas AV (w szarym okręu). Zapisy A i B pochodzą z tego samego badania EKG metodą Holtera z różnych okresów doby

Co więcej, po zastosowaniu algorytmów podobnych do MVP w przypadku wystąpienia zaburzeń przewodzenia $\mathrm{AV}$ nie istnieje mechanizm zabezpieczający przed bardzo długimi odstępami PQ - stymulacja komorowa nie zostanie zainicjowana, jeżeli pobudzenie komorowe wystąpi w którymkolwiek momencie między kolejnymi pobudzeniami przedsionkowymi (może to być tuż przed kolejnym pobudzeniem przedsionkowym). Inną kwestią są pauzy w pracy serca podczas kolejnych testów przewodzenia AV lub napadowych zaburzeń przewodzenia. Pacjenci mogą odczuwać nierówne bicie serca i pauzy podobnie jak odczuwają zahamowania zatokowe lub dodatkowe pobudzenia komorowe. W codziennej praktyce występują pacjenci, u których trzeba wyłączyć algorytmy promocji własnego rytmu komór z powodu subiektywnych objawów.

Podjęto liczne próby ustalenia optymalnego czasu trwania przewodzenia AV na podstawie pomiarów hemodynamicznych i badań echokardiograficznych. Najwięcej uwagi poświęcono optymalizacji programowania układów resynchronizujących serce, gdzie ma to szczególne znaczenie [13]. Wydaje się, że najkorzystniejszy w układach AV stymulujących serce pod względem hemodynamicznym jest czas przewodzenia AV 160-200 ms w zależności od metody oceny [14, 15]. W badaniu Ishikawy i wsp. [16] przy średnim odstępie AV 155 ms koniec fali A napływu mitralnego pokrywał się z całkowitym zamknięciem zastawki mitralnej, a dalsze jego wydłużanie skutkowało pojawieniem się niedomykalności zastawki dwudzielnej. Należy jednak pamiętać, że obserwacje te poczyniono na niezbyt licznych grupach chorych i bez wystandaryzowanego protokołu, w tym przy różnym tętnie, co, jak dowiedli Ovsyshcher i wsp. [17], ma duże znaczenia hemodynamiczne. Te badania wskazują na potrzebę racjonalnego wykorzystania algorytmów wydłużających czas AV w praktyce klinicznej.

Każda z firm produkujących urządzenia wszczepialne dysponuje własnymi algorytmami unikania stymulacji prawej komory. Znajomość ich specyfiki jest ważna dla osób opisujących badania EKG metodą Holtera, by uniknąć podejrzeń o nieprawidłowe funkcjonowanie urządzenia wszczepialnego, a także zminimalizować niekorzystny wpływ następstw hemodynamicznych.

W urządzeniach firmy Medtronic dostępnym algorytmem unikania stymulacji prawej komory jest algorytm MVP oraz algorytm SearchAV + (pozytywnej histerezy czasu AV). Algorytm MVP jest najlepiej przebadanym ze wszystkich dostępnych algorytmów zmniejszających stymulację prawej komory. Wiadomo, że wśród chorych, u których z powodu choroby węzła zatokowego lub napadowych zaburzeń przewodnictwa AV wszczepiono układ stymulujący, MVP istotnie zmniejszał odsetek stymulacji komorowej w porównaniu $z$ trybem $\mathrm{DDD}(\mathrm{R})$ [18].

W dalszej części przedstawiono najważniejsze mechanizmy działania rozwiązań stosowanych u pozostałych producentów. Celem tego opracowania jest zwrócenie uwagi na wykorzystywane mechanizmy, nie zaś dokładne ich przedstawienie. Kluczowe jest zrozumienie celu 
i mechanizmów działania algorytmów służących ograniczeniu odsetka stymulacji komorowej. W codziennej praktyce można korzystać z materiałów dostarczanych przez producentów sprzętu na ich stronach internetowych lub publikowanych opracowaniach skierowanych do elektrofizjologów. W przypadku wątpliwości warto skierować pacjenta na dodatkową kontrolę wszczepionego układu, koniecznie z „podejrzanym” fragmentem zapisu badania EKG.

W urządzeniach firmy Boston Scientific dostępne są dwa podobne do siebie algorytmy - reverse mode swich (RMS) oraz algorytm RYTHMIQ, będący nowszą wersją RMS. Istotą algorytmu RYTHMIQ jest jednoczesne działanie stymulatora w dwóch trybach stymulacji - w trybie AAI(R) oraz w trybie VVI z częstością rytmu o 15/min poniżej zaprogramowanego dolnego limitu tętna (VVI back-up), a w przypadku utraty przewodzenia AV zmiana trybu stymulacji na DDD(R). Do zmiany trybu stymulacji na DDD(R) dochodzi, kiedy spośród 11 pobudzeń urządzenie wykryje 3 komorowe, spełniające jedno z następujących kryteriów: stymulacja komorowa o typie VVI back-up, odstęp między kolejnymi pobudzeniami komorowymi będzie dłuższy niż dolny limit tętna w trybie AAI wydłużony o 150 ms lub odstęp między kolejnymi pobudzeniami komorowymi będzie dłuższy niż wynika ze stymulacji w trybie AAIR wydłużony o 150 ms [9]. Powrót do pierwotnego trybu następuje po zarejestrowaniu przez urządzenie 25 lub więcej pobudzeń komorowych podczas stopniowego wydłużania czasu AV. Różnicą między tym algorytmem a algorytmem MVP jest niedopuszczenie do pojawienia się pauz, dzięki aktywności stymulacji typu VVI, minusem rozwiązania firmy Boston Scientific jest generowanie asynchronii AV. W literaturze dostępne są dwa badania sprawdzające skuteczność działania algorytmów w stymulatorach Boston Scientific - jedno dotyczące algorytmu RMS [19], drugie dotyczące algorytmu RYTHMIQ [20]. Badania sugerują częste nieprawidłowe działanie algorytmów i podważają ich przydatność kliniczną.

W urządzeniach firmy Biotronik dostępny jest algorytm ventricular pacing suppression. Ze względu na stosunkowo duży odsetek pacjentów z implantowanymi urządzeniami firmy Biotronik wśród chorych z urządzeniami do elektroterapii serca algorytm ten wymaga dodatkowego omówienia. W przypadku aktywacji algorytmu układ wyjściowo pracujący w trybie DDD podejmuje kolejne próby zmiany trybu stymulacji w tryb ADI. Jeżeli układ nie rejestruje pobudzeń komorowych przewiedzionych droga fizjologiczną przez 30 s zaczyna wydłużać czas AV do 450 ms w 8 cyklach. W przypadku wykrycia zaprogramowanej liczby, między 1 a 8, kolejnych własnych pobudzeń komorowych dochodzi do zmiany trybu stymulacji na $A D I(R)$. Podczas pracy w trybie $A D I(R)$ urządzenie monitoruje własne przewodzenie AV w interwałach do $450 \mathrm{~ms}$ po każdym pobudzeniu przedsionkowym. W przypadku niewykrycia własnego pobudzenia komorowego w jednym cyklu urządzenie monitoruje rytm przez kolejnych 8 cykli pod kątem braku wystąpienia dwóch kolejnych przewiedzionych pobudzeń komorowych, braku wystąpienia zaprogramowanej (od 1 do 8) liczby przewiedzionych pobudzeń komorowych lub braku wyczutego pobudzenia komorowego przez $2 \mathrm{~s}$ (ten czas również może zostać zmieniony, przy czym nie jest to polecana modyfikacja). W przypadku spełnienia któregokolwiek z tych warunków następuje powrót do stymulacji w trybie $\operatorname{DDD}(\mathrm{R}) \mathrm{z}$ zaprogramowanym czasem AV. Schemat działania algorytmu Vp Suppression, kryteria wejścia i wyjścia z trybu stymulacji ADI, przedstawiono na rycinie 8 [4, 11]. W 2010 roku toczyło się badanie o akronimie Ventricular Pace Suppression Study (VpS) służące ocenie skuteczności tego algorytmu, jednak mimo jego zakończenia we wrześniu 2011 wyniki nie są dostępne [17].

Na rynku obecne są również rozwiązania produkowane przez grupę Sorin - AAISafeR, AAISafeR2 oraz Safe R. Liczba urządzeń tej firmy wśród polskich chorych jest bardzo mała. W typ przypadku wyjściowym trybem stymulacji jest tryb AAI(R). Jeżeli wystąpi jedno z czterech zdarzeń elektrycznych, to dochodzi do przełączenia trybu stymulacji na $\operatorname{DDD}(\mathrm{R})$. Te zdarzenia to brak wyczutego pobudzenia komorowego po każdym z dwóch kolejnych wyczutych pobudzeń przedsionkowych (interpretowane przez urządzenie jako blok AV III stopnia bez rytmu zastępczego), 3 epizody braku wyczutego pobudzenia komorowego po wyczutym pobudzeniu przedsionkowym w ciągu 12 kolejnych elektrycznych ewolucji serca (interpretowane przez urządzenie jako blok AV II stopnia), 6 kolejnych ewolucji elektrycznych serca z dłuższym niż zaprogramowany odstępem AV (> 350 ms dla pobudzeń wyczutych i ponad 450 ms dla pobudzeń wystymulowanych) lub wystąpienie pauzy definiowanej jako odstępu między wyczutymi pobudzeniami komorowymi między 2 a 4 s zależnie od zaprogramowania. Następnie urządzenie próbuje powrócić do trybu stymulacji $A A I(R)$ po 12 kolejnych wyczutych pobudzeniach komorowych lub co 100 komorowych pobudzeń wystymulowanych. W przypadku dużej liczby zmian z trybu $\operatorname{AAI}(R)$ do $\operatorname{DDD}(\mathrm{R})$ urządzenie może przez dłuższy czas pozostać w trybie stymulacji $\operatorname{DDD}(\mathrm{R})$ (ryc. 8) [9, 21].

Firma Abbott proponuje algorytm autointrinsic conduction search i jego nowszą wersje - ventricular intrinsic preference (VIP). Główną zasadą działania algorytmu VIP jest regularna ocena własnego przewodzenia AV do maksymalnego opóźnienia wynoszącego 350 ms. W przypadku rejestracji własnego pobudzenia komorowego urządzenie utrzymuje wydłużony czas AV. Brak pojawiania się pobudzenia komorowego dezaktywuje algorytm [4]. Istnieją dwa doniesienia dotyczące skuteczności tego algorytmu. W obu badaniach wykazano istotne zmniejszenie odsetka stymulacji prawokomorowej u chorych z aktywowanym algorytmem VIP [22, 23]. 


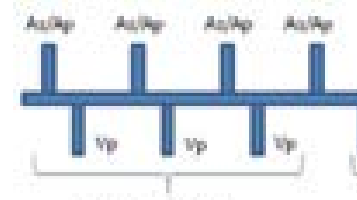

Stymulacja komorowa przez 305
Monitorowanie praez 8 cykli. Wystąpienie zaprogramowancjliczby (pomiędzy 1 a 8; nominalnie 6z 8) wyczutych pobudzen $\rightarrow$ zmiana stymulacī na ADN(R)
Stymulacja

ADE(R)

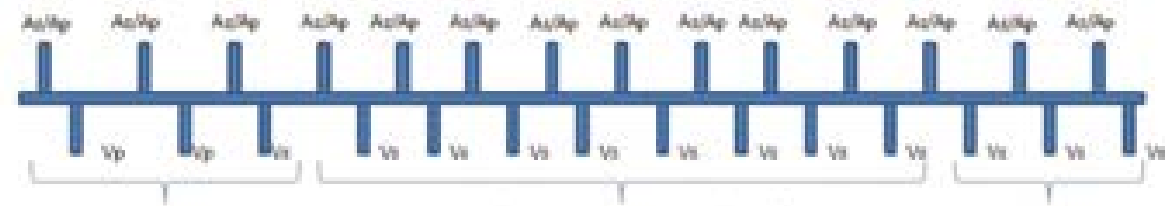

Wyczute pobudzenie komorowe
Monitorowanie praez 8 cykli. Wrstapieniezaprogramowanej liczby (pomiędzy 1 a 8; nominalnie $6 z$ ) wycrutych pobudzen $\rightarrow$ zmiana stymulacji na ADI(R)
Stymulacia ADQR)

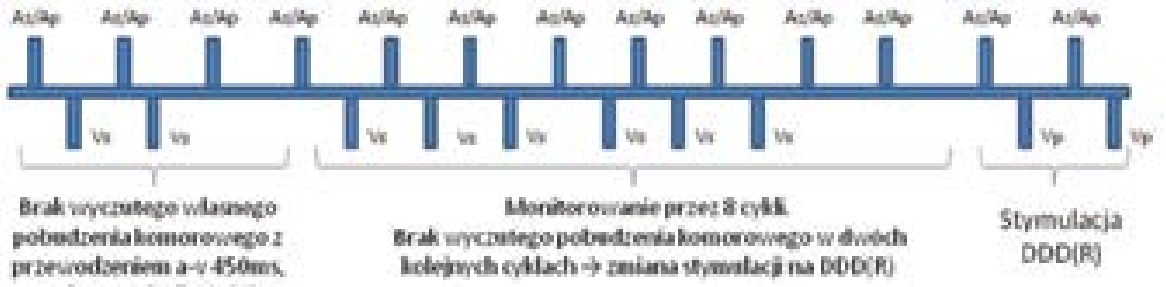
tryb spanstucia ADE R)

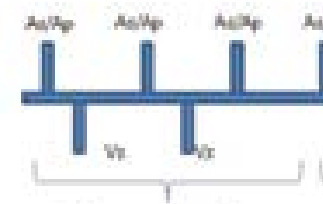

Bral wryubego wanesto potodtewiskemerewezo ?

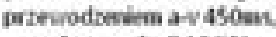
syb invalaci ADQ K]

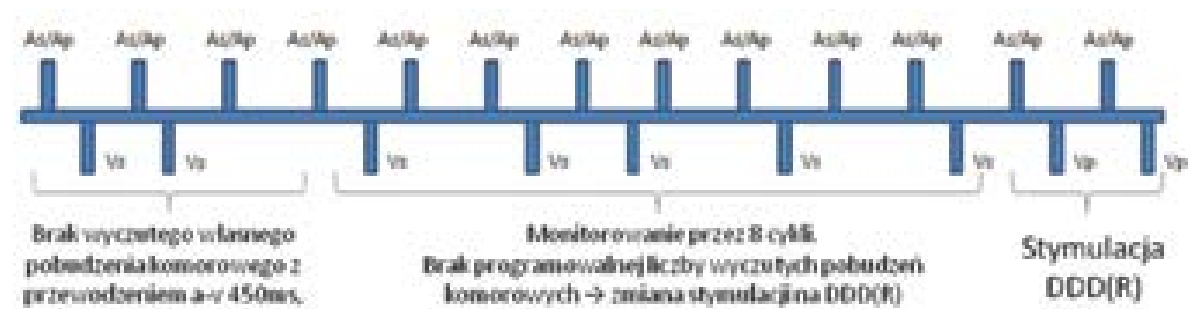

Rycina 8A-C. Warunki zmiany trybu stymulacji serca z DDD na ADI i z ADI na DDD przy aktywnym algorytmie Vp Superssion w urządzeniach firmy Biotronik; As - pobudzenie przedsionkowe własne pacjenta; Ap - pobudzenie przedsionkowe wystymulowane; Vs - pobudzenie komorowe własne pacjenta; $\mathrm{Vp}$ - pobudzenie komorowe wystymulowane 


\section{Podsumowanie}

Algorytmy unikania stymulacji prawej komory mogą przypominać nieprawidłowe działanie układu wszczepialnego i dlatego ich znajomość jest ważna dla lekarzy opisujących badania EKG metodą Holtera. Ważne jest również, by na skierowaniu na badanie umieszczać nazwę firmy, która wyprodukowała wszczepione urządzenie na skierowaniu, co bardzo ułatwia interpretację opisywanych zapisów. Niektóre urządzenia mogą dopuszczać występowanie bloków AV II stopnia, bardzo długie odstępy AV lub całkowita dyssynchronię AV.

\section{Konflikt interesów}

Autorzy deklarują brak konfliktu interesów.

\section{Abstract}

High percentage of right ventricular pacing is associated with an increased risk of adverse clinical events such as worsening of heart failure symptoms or atrial fibrillation. Right ventricular pacing should be minimized especially in patients with heart failure and reduced left ventricular ejection fraction after implantation of one- or two-chamber cardioverter-defibrillator. Adequate atrioventricular delay programming or appropriate pacing mode programming that promotes patients own rhythm for example AAI/DDD or DDD/ADI helps in avoiding right ventricular pacing. There are special algorithms, different between pacemaker-producing companies, basing on the above methods that spare right ventricular pacing. Some of those algorithms can mimic pacemaker dysfunction and can be a challenge during Holter electrocardiogram (ECG) interpretations. In this article Holter ECG examples of different algorithms to reduce right ventricle pacing are presented and discussed.

Key words: Holter ECG, avoiding right ventricular pacing, electrocardiogram

Folia Cardiologica 2018; 13, 1: 86-95

\section{Piśmiennictwo}

1. Chęciński L, Sławuta A, Moszczyńska-Stulin J, et al. Wpływ przewlekłej stymulacji prawej komory - aspekty elektrofizjologiczne, neurohumoralne, histopatologiczne i hemodynamiczne. Folia Cardiol. 2016; 10(6): 410-417, doi: 10.5603/fc.2015.0078.

2. Delgado V, Tops LF, Trines SA, et al. Acute effects of right ventricular apical pacing on left ventricular synchrony and mechanics. Circ Arrhythm Electrophysiol. 2009; 2(2): 135-145, doi: 10.1161/CIRCEP.108.814608, indexed in Pubmed: 19808458.

3. $\mathrm{Xu} \mathrm{H}, \mathrm{Xie} X, \mathrm{Li}$ J, et al. Early right ventricular apical pacing-induced gene expression alterations are associated with deterioration of left ventricular systolic function. Dis Markers. 2017; 2017: 8405196, doi: 10.1155/2017/8405196, indexed in Pubmed: 28928601.

4. Auricchio A, Ellenbogen KA. Reducing ventricular pacing frequency in patients with atrioventricular block: is it time to change the current pacing paradigm? Circ Arrhythm Electrophysiol. 2016; 9(9), doi: 10.1161/CIRCEP.116.004404, indexed in Pubmed: 27637555.

5. Akerström F, Arias MA, Pachón M, et al. The importance of avoiding unnecessary right ventricular pacing in clinical practice. World J Cardiol. 2013; 5(11): 410-419, doi: 10.4330/wjc.v5.i11.410, indexed in Pubmed: 24340139.

6. Sweeney MO, Hellkamp AS, Ellenbogen KA, et al. MOde Selection Trial Investigators. Adverse effect of ventricular pacing on heart failure and atrial fibrillation among patients with normal baseline QRS duration in a clinical trial of pacemaker therapy for sinus node dysfunction. Circulation. 2003; 107(23): 2932-2937, doi: 10.1161/01. CIR.0000072769.17295.B1, indexed in Pubmed: 12782566.

7. Sharma AD, Rizo-Patron C, Hallstrom AP, et al. DAVID Investigators. Percent right ventricular pacing predicts outcomes in the
DAVID trial. Heart Rhythm. 2005; 2(8): 830-834, doi: 10.1016/j. hrthm.2005.05.015, indexed in Pubmed: 16051118.

8. Brignole M, Auricchio A, Baron-Esquivias G, et al. Wytyczne ESC dotyczące stymulacji serca i terapii resynchronizującej w 2013 roku. Kardiol Pol. 2013; 71(Suppl V): 133-192, doi: 10.5603/kp.2013.0182.

9. Akerström F, Pachón M, Puchol A, et al. Chronic right ventricular apical pacing: adverse effects and current therapeutic strategies to minimize them. Int J Cardiol. 2014; 173(3): 351-360, doi: 10.1016/j. ijcard.2014.03.079, indexed in Pubmed: 24721486.

10. Sweeney MO, Bank AJ, Nsah E, et al. Search AV Extension and Managed Ventricular Pacing for Promoting Atrioventricular Conduction (SAVE PACe) Trial. Minimizing ventricular pacing to reduce atrial fibrillation in sinus-node disease. N Engl J Med. 2007; 357(10): 1000-1008, doi: 10.1056/NEJMoa071880, indexed in Pubmed: 17804844.

11. Cunnington $C . A A I(R)-D D D(R)$ mode switch algorithms to minimise right ventricular pacing. http://www.bhrs.com/editorial-minimise-right-ventricular-pacing (dostęp 04.11.2017).

12. Antonini L, Auriti A, Pasceri V, et al. Optimization of the atrioventricular delay in sequential and biventricular pacing: physiological bases, critical review, and new purposes. Europace. 2012; 14(7): 929-938, doi: 10.1093/europace/eur425, indexed in Pubmed: 22310153.

13. Antonini L, Auriti A, Pasceri V, et al. Optimization of the atrioventricular delay in sequential and biventricular pacing: physiological bases, critical review, and new purposes. Europace. 2012; 14(7): 929-938, doi: 10.1093/europace/eur425, indexed in Pubmed: 22310153.

14. Ritter P, Padeletti L, Gillio-Meina L, et al. Determination of the optimal atrioventricular delay in DDD pacing. Comparison between echo and peak endocardial acceleration measurements. Europace. 
1999; 1(2): 126-130, doi: 10.1053/eupc.1998.0032, indexed in Pubmed: 11228855

15. Dupuis JM, Kobeissi A, Vitali L, et al. Programming optimal atrioventricular delay in dual chamber pacing using peak endocardial acceleration: comparison with a standard echocardiographic procedure. Pacing Clin Electrophysiol. 2003; 26(1 Pt 2): 210-213, doi: 10.1046/j.14609592.2003.00018.x, indexed in Pubmed: 12687814.

16. Ishikawa T, Sumita S, Kimura K, et al. Prediction of optimal atrioventricular delay in patients with implanted DDD pacemakers. Pacing Clin Electrophysiol. 1999; 22(9): 1365-1371, doi: 10.1111/j.15408159.1999.tb00630.x, indexed in Pubmed: 10527018.

17. Ovsyshcher I, Zimlichman R, Katz A, et al. Measurements of cardiac output by impedance cardiography in pacemaker patients at rest: effects of various atrioventricular delays. J Am Coll Cardiol. 1993; 21(3): 761-767, doi: 10.1016/0735-1097(93)90110-m, indexed in Pubmed: 8436759.

18. Gillis $\mathrm{AM}$, Pürerfellner $\mathrm{H}$, Israel $\mathrm{CW}$, et al. Medtronic Enrhythm Clinical Study Investigators. Reducing unnecessary right ventricular pacing with the managed ventricular pacing mode in patients with sinus node disease and AV block. Pacing Clin Electrophysiol. 2006; 29(7): 697-705, doi: 10.1111/j.1540-8159.2006.00422.x, indexed in Pubmed: 16884504.
19. Akerström F, Arias MA, Pachón M, et al. The reverse mode switch algorithm: how well does it work? Heart Rhythm. 2013; 10(8): 1146-1152, doi: 10.1016/j.hrthm.2013.05.025, indexed in Pubmed: 23732226.

20. Strik M, Defaye P, Eschalier R, et al. Performance of a specific algorithm to minimize right ventricular pacing: a multicenter study. Heart Rhythm. 2016; 13(6): 1266-1273, doi: 10.1016/j. hrthm.2016.02.008, indexed in Pubmed: 26899544.

21. www.livanova.sorin.com/file/download-508.action (dostęp 04.11. 2017).

22. Yadav R, Jaswal A, Chennapragada S, et al. Effectiveness of Ventricular Intrinsic Preference (VIPTM) and Ventricular AutoCapture (VAC) algorithms in pacemaker patients: results of the validate study. J Arrhythm. 2016; 32(1): 29-35, doi: 10.1016/j.joa.2015.07.004, indexed in Pubmed: 26949428.

23. Bauer A, Vermeulen J, Toivonen L, et al. Minimizing right ventricular pacing in pacemaker patients with intact and compromised atrioventricular conduction: results from the EVITA Trial. Herzschrittmacherther Elektrophysiol. 2015; 26(4): 359-366, doi: 10.1007/ /s00399-015-0394-2, indexed in Pubmed: 26315154. 